\title{
Enhancing Brand Awareness, Reputation and Loyalty: The Role of Social Media
}

\author{
Roberto Chierici ${ }^{1}$, Barbara Del Bosco ${ }^{1}$, Alice Mazzucchelli ${ }^{1} \&$ Claudio Chiacchierini ${ }^{1}$ \\ ${ }^{1}$ University of Milano - Bicocca, Milan, Italy \\ Correspondence: Roberto Chierici, Department of Business and Law, University of Milano - Bicocca, Milan, \\ Italy. E-mail: roberto.chierici@unimib.it
}

Received: October 27, 2018

Accepted: November 28, 2018

Online Published: December 31, 2018

doi:10.5539/ijbm.v14n1p216

URL: https://doi.org/10.5539/ijbm.v14n1p216

\begin{abstract}
The paper analyzes three models in order to identify the causal combinations of social media usage and management that lead to an improvement of, respectively, brand awareness, brand reputation, and brand loyalty. Data collected from 268 managers operating in organizational units closely involved in marketing and communication activities have been analyzed using fuzzy-set qualitative comparative analysis (fsQCA). Different equifinal pathways emerge, highlighting some commonalities, as well as some specificities. Social media integration with other communication channels and dissemination of information collected through social media within the organization turn out to be two managerial practices with a relevant role in achieving higher brand awareness, brand reputation, and brand loyalty. Moreover, social media responsiveness appears to be crucial for enhancing brand loyalty. These results contribute to the branding and social media literature, providing also interesting insights for practitioners to understand how to strength brands in the social media era.
\end{abstract}

Keywords: social media, brand awareness, brand reputation, brand loyalty, fsQCA

\section{Introduction}

An important share of firms' value is related to the value of their brands, which are crucial elements in the relationship with customers (Aaker, 1992). This attaches importance to brand management and to the various firms' activities that may affect brand awareness, reputation, and customers' loyalty to the brand. In recent years, the growth in the use of social media by individuals to communicate and share contents with other users has generated opportunities and challenges for firms, offering a new tool to interact with current and potential customers (Kaplan \& Haenlein, 2010) and share information about brands and products (Kumar, Choi, \& Greene, 2017). Many firms have activated social media accounts as a part of their marketing and communication strategies in order to exploit these potentialities and engage customers with their brands. Social media have become fundamental for firms to actively communicate with customers, to establish long-lasting relationships, to share contents and to advertise brands (Ismail, 2017). Joining social media provides a unique opportunity for firms to strength their brands, helping to increase business value such as creating brand awareness, brand reputation and brand loyalty (Alberghini, Cricelli, \& Grimaldi, 2014). While social media are now recognized as critical elements of marketing strategies and their availability is widespread, firms are still struggling to understand how to effectively use and manage social media in order to achieve better brand performances (Haenlein, 2017), and there is an ongoing debate about branding strategies in the social media context. In this regard, a number of theoretical lens and various contexts have been used to investigate the effect of social media on different branding constructs (Yuksel, Milne, \& Miller, 2016). In fact, many studies have analyzed customers' perceptions of the effect of social media on brand engagement (Hollebeek, Glynn, \& Brodie, 2014; Laroche, Habibi, \& Richard, 2013), on brand communities (Heydari \& Laroche, 2018), on brand trust (Habibi, Laroche, \& Richard, 2014) and on brand equity (Hsu \& Lawrence, 2016). However, little attention has been devoted to the contribution of social media activities to brand performances from a managerial perspective, and the effectiveness of social media usage and which managerial choices lead to better outcomes are still not clear (Brodie, Hollebeek, Juric, \& Ilic, 2011; Godey et al., 2016). More specifically, despite the wide body of literature on social media from a consumer perspective, few empirical studies have focused on the role of social media in boosting a brand by analyzing the managerial perspective.

In order to fill this gap, this paper contributes to the existing branding and social media literature by empirically 
investigating which choices regarding social media use and management are associated with better results in terms of brand awareness, brand reputation, and brand loyalty. The paper presents a study of a sample of 268 firms located in Italy. Data were collected through an online questionnaire sent to managers operating in organizational units closely involved in marketing and communication activities. Using fsQCA, the study explores how social media information generation, internal information dissemination, responsiveness, integration with other media and their complementary use collectively result in high brand awareness, high brand reputation and high brand loyalty.

This research contributes to a better understanding of which managerial choices regarding social media usage and management effectively foster brand awareness, brand reputation and brand loyalty, leading to interesting implications for both research and management. First, the addition and integration of social media into a firm's communication mix increase communication efficacy, enhancing brand awareness and brand reputation. Second, internal sharing of information facilitates the firm's ability to create a consistent brand communication across different media and, in turn, to strengthen brand reputation. Third, engaging customers through timely responses and active interactions via social media enables firms to boost their brand loyalty. Finally, results show that the enhancement of brand awareness and brand loyalty can be obtained also by combining the use of different managerial practices.

The remainder of the paper is organized as follows. The next section presents a review of the extant literature on social media and brand management. Thereafter, the paper describes the methodology applied and presents the results. A discussion of the main findings is then presented, followed by an analysis of managerial implications for practitioners and limitations.

\section{Theoretical Framework: Social Media As Brand Management Enablers}

The proliferation of social media has transformed the strategies firms use to interact and engage with existing and potential customers (Mangold \& Faulds, 2009). Firms are increasingly using social media, especially by operating pages on social networking sites, to interact, share information, develop long lasting relationships with devoted customers, attract new customers who would otherwise be out of reach (Gallaugher \& Ransbotham, 2010; Tsimonis \& Dimitriadis, 2014), and build brand (de Vries, Gensler, \& Leeflang, 2017; Swani, Milne, Brown, Assaf, \& Donthu, 2017; Yoshida, Gordon, Nakazawa, Shibuya, \& Fujiwara, 2018). In this way, social media have become a new strategic marketing tool that enables firms to promote better their brands (Kozinets, de Valck, Wojnicki, \& Wilner, 2010) and through which customers can acquire and share information, and interact with their favorite brands (Chappuis, Gaffey, \& Parvizi, 2011; Qualman, 2013). Social media have allowed firms to establish their own brand communities, a virtual environment where firms and users can stay in touch, easily share information about products and services, provide customers with real-time support, and boost brand performances (Laroche, Habibi, \& Richard, 2013; Swani et al., 2017). Building and enhancing brands' presence in social media provide firms with greater access to customers' information, needs and opinions. Thus, firms are increasingly interested in using social media in a complementary mode to generate, disseminate, integrate, and respond to information obtained from social media interactions (Agnihotri, Dingus, $\mathrm{Hu}$, \& Krush, 2016; Trainor, Andzulis, Rapp, \& Agnihotri, 2014) in order to develop effective brand building activities (Tsimonis \& Dimitriadis, 2014). Hence, social media complete traditional communication tools to engage customers with the brand. In this context, joining social media provides a unique opportunity for firms to strengthen their brands, helping in increasing business value such as creating brand awareness, brand reputation and brand loyalty (Alberghini et al., 2014).

\subsection{Brand Awareness}

Letting consumers know and recognize a brand is one of the main goals of a firm's brand management (Aaker, 1992). The most important advantage for firms in enhancing brand awareness is strengthening the presence of their brands in consumers' memories and, in turn, influencing customers' associations and decision-making processes with regard to a specific brand (Keller, 2008). Social media provide firms with an effective way to increase brand awareness, by exposing a huge number of consumers to their brands (Kumar et al., 2017). Social media activities are not limited to sharing marketing communications, but also extend links with customers and act as an important means for establishing, consolidating, and maintaining brand awareness (Tiago \& Veríssimo, 2014). Thus, informing and engaging consumers with an active and integrated brand's presence in social media can create and raise brand awareness, boosting brand recognition and recall (Hutter, Hautz, Dennhardt, \& Füller, 2013; Tsimonis \& Dimitriadis, 2014). By using social media, firms can share product experiences and opinions in real time, generating awareness and interest (Berger \& Milkman, 2012) in a new and easier way. Brand awareness derives from anything that makes consumers experience the brand and, in this perspective, social 
media certainly represent a way to expose consumers to the brand and generate brand awareness (Hutter et al., 2013). As a result, firms are actively engaging customers in their social media marketing strategies (Neff, 2014). It follows that the more actively firms use and manage social media, the higher the brand awareness will be.

\subsection{Brand Reputation}

Brand reputation is a highly valuable asset for firms because it is related to the perceptions and the associations held in consumers' minds about a brand over time (Keller, 1993). Brand reputation refers to the consumers' perceptual representation of brand's past actions, results, and future expectations, affecting consumers' attitudes and behaviors (Fombrun \& Rindova, 1996). In order to boost their sales and generate business success, firms aim to build, maintain and monitor a favorable brand reputation (de Chernatony, 1999). By using social media as a powerful marketing and communication tool, firms can create and improve their brand reputation, sharing contents and facilitating interactions not only between brands and consumers but also among consumers (Kim \& Ko, 2012). Social media are now "a legitimate, trusted voice that resonates with consumers" (Jin, 2012, p. 687), affecting consumers' preferences and decisions. In this regard, several studies have shown that social media can positively affect brand reputation if firms actively use and manage social media as an integrated and complementary part of their communication mix (Booth \& Matic, 2011; Dijkmans, Kerkhof, \& Beukeboom, 2015; Kim \& Ko, 2010, 2012). In other words, the more social media are effectively used and managed by firms, the more likely firms achieve a favorable brand reputation.

\subsection{Brand Loyalty}

Due to its strategic relevance both in consumers' behavior and in brand management, brand loyalty is a key concept in marketing literature. Brand loyalty has been defined as the attachment that a customer has to a brand (Aaker, 1991), leading customers to repeat their purchasing behaviors in the future (Oliver, 1999). In order to develop and maintain customers' brand loyalty, firms have exploited both traditional and new tools (Keller, 2008; Kotler \& Keller, 2007). In recent years, firms have been focusing their attention especially on social media in order to understand if and how these new tools contribute to improving customer loyalty (Hollebeek et al., 2014; Yoshida et al., 2018). In fact, within the social media environment, firms can better engage with their devoted customers on a multitude of levels (Krishen, Berezan, Agarwal, \& Kachroo, 2016), by developing direct and personal relationships and offering unique and seamless customer experiences (Rapp, Beitelspacher, Grewal, \& Hughes, 2013). Social media allow firms to develop and increase brand loyalty through networking, conversation and community building features (Erdoğmuş \& Çiçek, 2012; Krishen, Trembath, \& Muthaly, 2015). In particular, information generation, sharing and social media responsiveness enable firms to provide regular brand communications, strengthen consumer-brand relationships, reduce customers' efforts to find information about a brand, and, in turn, increase brand loyalty (Ismail, 2017). As highlighted also by Raab et al. (2016) firms that use social media in an interactive, customized, attentive and responsive way are more likely to engage customers and improve brand loyalty. It can be concluded that the more actively firms use and manage social media the higher the brand loyalty will be.

While previous studies have focused on the effect of social media capabilities as a unique combination of firms' ability in using and managing information gathered from social media on customer relationship performance (Trainor et al., 2014), this paper aims to investigate different dimension of social media capabilities, namely information generation, internal information dissemination and responsiveness, separately to better understand how different social media usages contribute to enhance firms' performance. Moreover, the paper intends to deeply analyze three different dimensions of brand performance that can be considered crucial to enhance customer relationship and engage customer in a more efficient way. Finally, since the boundaries between online and offline communication channels are blurring (Vernuccio \& Ceccotti, 2015) and communication mix are integrating traditional and new interactive media in a more coordinated way (Killian \& McManus, 2015), this paper also tries to shed light on how the degree of social media integration with other media and social media usage in a complementary mode or as substitute for other channel affect brand performance. Figure 1 presents the framework of the analysis conducted. 


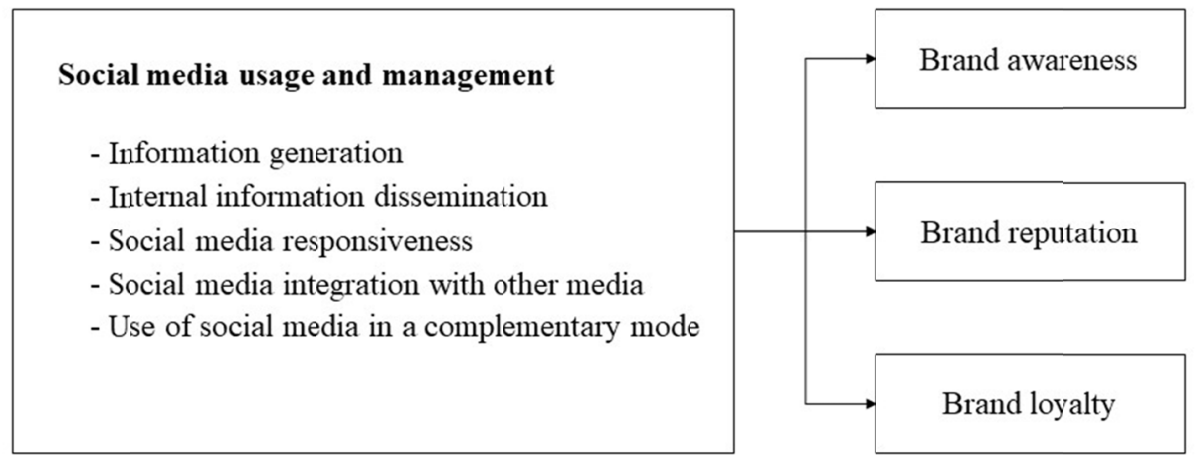

Figure 1. The framework of the analysis

\section{Method}

\subsection{Sample and Data}

The objective of this study is to investigate social media management choices that can lead to an improvement in brand awareness, reputation and loyalty.

To achieve this objective, data were collected from firms located in Italy and operating in primary, industrial and service sectors of activity. The Italian market is a suitable context for social media research because Italian consumers actively use social media platforms to seek information, share experiences and engage with brands (Kemp, 2017). In order to conduct the survey, an online questionnaire was distributed to 3,216 managers belonging to organizational units closely involved in marketing and communication activities of industrial and service companies operating in Italy. Data gathering lasted from April to May 2017, leading to 268 valid responses $(8.33 \%$ response rate). This rate is in line with the response rate range commonly reached by online surveys (Anseel, Lievens, Schollaert, \& Choragwicka, 2010; Cycyota \& Harrison, 2006).

Of the total sample, the majority of respondents operate within large and medium firms (respectively $47.4 \%$ and $32.7 \%$ ) and, with reference to the fields of activity, the majority of firms operate in (commercial and other) services $(54.1 \%)$, followed by manufacturing $(41.5 \%)$, and primary, energy and mining sector $(4.4 \%)$.

The questionnaire adapted multi-item scales validated by extant literature (Trainor et al., 2014) to investigate firms' practices concerning information collection through social media (information generation), the sharing of this information among internal organizational positions (internal information dissemination), and the response provided by the firm to social media users (social media responsiveness). In addition, the questionnaire explored how the firms introduced social media into their communication mix, using social media as a complement or substitute for other channels, and explored the level of integration with the management of other media (Dalla Pozza, 2014). Finally, managers were asked to evaluate on 5-point Likert scales the efficacy of the use of social media by their firms in terms of brand awareness, brand reputation and brand loyalty (Aaker, 1992; Keller, 1993). Table 1 presents a description of causal conditions and outcomes.

Table 1. Causal conditions and outcomes

\begin{tabular}{ll}
\hline Causal conditions & \\
\hline fs_information_generation & Information generation (multi-item scale) \\
fs_information_dissemination & Internal information dissemination (multi-item scale) \\
fs_responsiveness & Social media responsiveness (multi-item scale) \\
fs_integrated_management & Social media integration with other media (Fully integrated=1; Partially integrated=0.5; Fully \\
& independent=0) \\
fs_complementary_use & Use of social media in a complementary mode (Social media as complement for other channels=1; Social \\
\hline Outcomes & media as substitute for other channels=0) \\
\hline fs_awareness & Brand awareness (managers' evaluation of the impact of the use of social media on brand awareness) \\
fs_reputation & Brand reputation (managers" evaluation of the impact of the use of social media on brand reputation) \\
fs_loyalty & Brand loyalty (managers' evaluation of the impact of the use of social media on brand loyalty) \\
\hline
\end{tabular}




\section{$3.2 f_{s} Q C A$ and Variables Calibration}

In order to investigate the configuration framework, the study used a fuzzy-set qualitative comparative analysis (fsQCA) approach (Fiss, 2007; Ragin, 2008). Following the configurational theory, fsQCA is particularly appropriate for this study since it permits to investigate holistic relationships between causal conditions and outcomes and to identify alternative combinations of conditions that lead to an outcome rather than simply identify correlations between independent and dependent variables (Fiss, 2007). In particular, fsQCA enables us to point out causal conditions or configurations of causal conditions that are sufficient or necessary for the presence of the outcome of interest (Ragin, 2008; Schneider \& Wagemann, 2012). fsQCA focuses on the synergistic effect of several condition sets and successfully addresses the concept of "equifinality", according to which the same outcome can be achieved through multiple paths of causal conditions (Ragin, 2000).

This study analyzes three models in order to identify the causal combinations of social media usage and management that lead to an improvement of brand awareness, brand reputation and brand loyalty, respectively. The first model analyzes the relationship between the set of causal conditions and brand awareness, as an outcome condition; the second one analyzes the causal configurations useful to reach brand reputation, and the last one identifies the alternative paths that lead to brand loyalty. Using 3.0 fsQCA software (Ragin \& Sean, 2016), conditions and outcomes are calibrated to produce fuzzy-set scores that reflect the varying degrees to which different cases are members of a set (Ragin, 2000, 2008). In this perspective, the study applies the direct method of calibration, consisting of using three calibration anchors (full membership 0.95; crossover point 0.50 ; full non-membership 0.05) (Woodside, 2013). As suggested by Leischnig and Kasper-Brauer (2015), multi-item scales were combined into an average score, and the three qualitative anchors for calibration were identified by value 5 (full membership), value 1 (full non-membership), and value 3 (crossover point).

Then, for each outcome, the analysis of necessary conditions and a sufficiency test through the truth table were carried out (Fiss, 2007; Schneider \& Eggert, 2014; Schneider, Schulze-Bentrop, \& Paunescu, 2010).

\section{Results}

\subsection{Necessary and Sufficient Conditions}

According to Schneider et al. (2010), a condition or a combination of conditions is necessary for a specific outcome if it is always present when the outcome takes place and its consistency score is greater than 0.90 . Findings reveal that none of the conditions is necessary for the presence of brand awareness, brand reputation and brand loyalty because they do not exceed the threshold of 0.90 . However, taking into account the necessary conditions for the absence of the three outcomes, different results emerge. In fact, either the absence of information generation or the absence of information are necessary conditions for the absence of brand awareness. Additionally, the absence of information generation, or the absence of information dissemination or the absence of responsiveness are necessary for the absence of brand reputation. Finally, the absence of information generation is a necessary condition for the absence of brand loyalty.

With regard to sufficiency analysis, a condition or a combination of conditions is sufficient for a specific outcome if the presence of that condition or combination allows the outcome to be achieved and its consistency score exceeds 0.75 (Ragin, 2006). This study performed three separate truth table analyses, one for brand awareness, one for brand reputation and the last for brand loyalty, with a consistency cutoff of 0.90 , as suggested by Ragin (2000) and Schneider et al. (2010). Outcomes of fsQCA are presented in the following sections.

\subsection{Analysis of the Outcome Condition: Brand Awareness}

Model 1: fs_awareness $=\mathrm{f}$ ( $\mathrm{fs} \_$information_generation, fs_information_dissemination, fs_responsiveness, fs_integrated_management, fs_complementary_use)

The first model has two paths that lead to the presence of brand awareness (Table 2). The first path suggests that social media integration with other media is a sufficient and core condition for achieving a higher level of brand awareness (consistency $=0.82$; coverage $=0.86$ ). The second one indicates that social media complementary use combined with a high level of internal information dissemination as core conditions is sufficient for achieving high brand awareness (consistency $=0.96$; coverage $=0.45$ ). The solution has a high overall consistency $(0.83)$ and a high overall coverage (0.91). 
Table 2. Brand awareness - analysis of sufficient conditions

\begin{tabular}{lcc}
\hline Condition & Solution \\
\hline & & \\
\hline fs_information_generation & & \\
fs_information_dissemination \\
fs_responsiveness \\
fs_integrated_management \\
fs_complementary_use
\end{tabular}

\subsection{Analysis of the Outcome Condition: Brand Reputation}

Model 2: fs_reputation $=\mathrm{f}$ (fs_information_generation, fs_information_dissemination, fs_responsiveness, fs_integrated_management, fs_complementary_use)

The second model of the causal conditions relating to high brand reputation suggests two pathways (Table 3). Pathway one suggests that a high level of social media integration with other media is a sufficient and a core condition that can lead to higher brand reputation (consistency $=0.83$; coverage $=0.86$ ). Pathway two indicates that also a high level of internal information dissemination is sufficient and a core condition useful to improve brand reputation $($ consistency $=0.97$; coverage $=0.53$ ). Overall, the solution has a high consistency $(0.83)$ and a high coverage $(0.92)$.

Table 3. Brand reputation - analysis of sufficient conditions

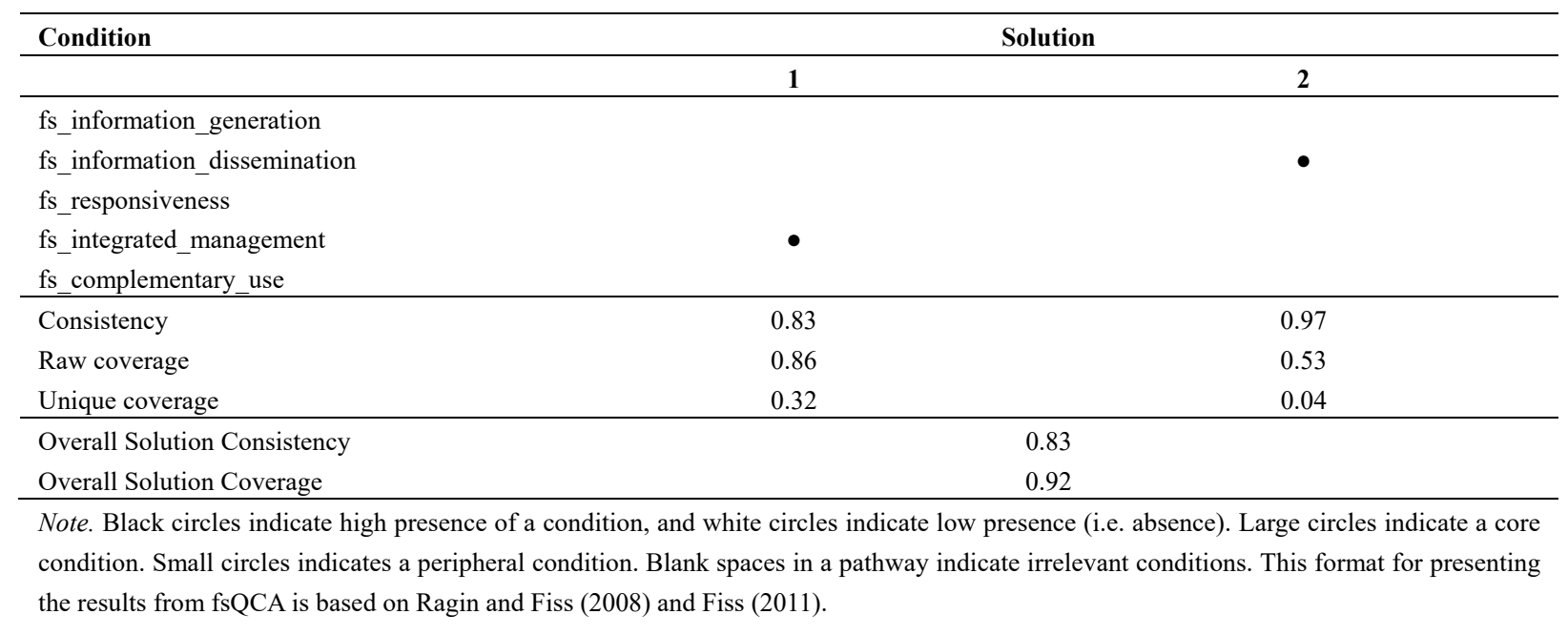

\subsection{Analysis of the Outcome Condition: Brand Loyalty}

Model 3: fs_loyalty $=\mathrm{f}$ (fs_information_generation, fs_information_dissemination, fs_responsiveness, fs_integrated_management, fs_complementary_use)

Table 4 shows four equifinal roots to brand loyalty. These paths illustrate the different ways social media may be used for reaching brand loyalty. More in detail, results indicate that high social media responsiveness is a sufficient and a core condition to reach a high level of brand loyalty (consistency $=0.93$; coverage $=0.67$ ). Moreover, findings suggest that using social media in a complementary mode leads to high brand loyalty if combined with a) high level of internal information dissemination (consistency $=0.93$; coverage $=0.49$ ) or b) 
high level of social media integration with other media and high level of information generation, as peripheral conditions (consistency $=0.94$; coverage $=0.43$ ). Finally, a high level of brand loyalty can be achieved also by combining a high level of internal information dissemination, high level of information generation and high level of social media integration with other media, as peripheral conditions (consistency $=0.96$; coverage $=0.41$ ). Overall, the solution has a high consistency $(0.91)$ and a satisfactory coverage $(0.75)$.

Table 4. Brand loyalty - analysis of sufficient conditions

\begin{tabular}{|c|c|c|c|c|}
\hline \multirow[t]{2}{*}{ Condition } & \multicolumn{4}{|c|}{ Solution } \\
\hline & 1 & 2 & 3 & 4 \\
\hline fs_information_generation & & & • & $\cdot$ \\
\hline fs_information_dissemination & & - & & • \\
\hline fs_responsiveness & $\bullet$ & & & \\
\hline fs_integrated_management & & & - & • \\
\hline fs_complementary_use & & $\cdot$ & • & \\
\hline Consistency & 0.93 & 0.93 & 0.94 & 0.96 \\
\hline Raw coverage & 0.67 & 0.49 & 0.43 & 0.41 \\
\hline Unique coverage & 0.14 & 0.03 & 0.02 & 0.01 \\
\hline Overall Solution Consistency & & & & \\
\hline Overall Solution Coverage & & & & \\
\hline
\end{tabular}

Figure 2 summarizes and compares results regarding sufficient conditions that allow the improvement of different dimensions of brand performance.

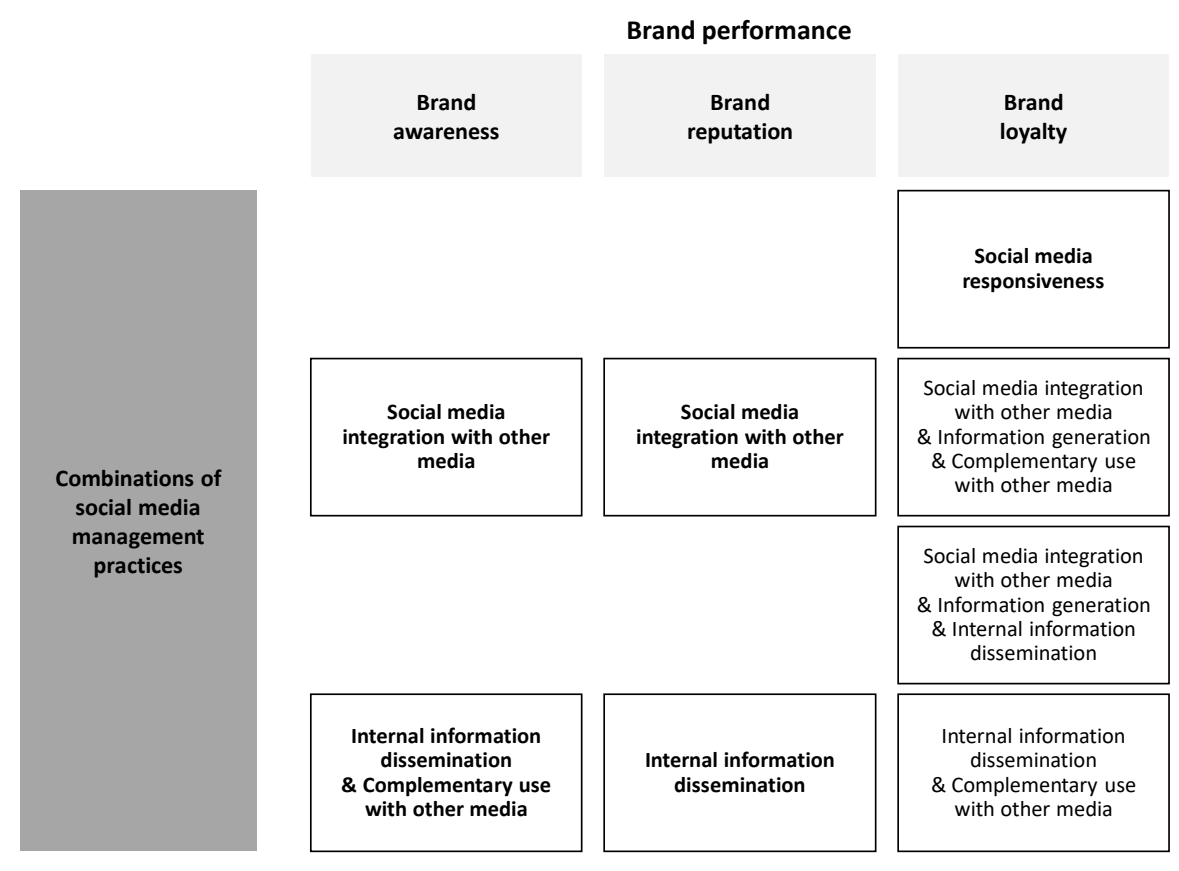

Figure 2. A synthesis of results

\section{Discussion}

This study investigated which choices regarding social media management are associated with better results in 
terms of brand awareness, brand reputation, and brand loyalty. Through a questionnaire, managers were asked to provide (1) information on how their firms use social media to communicate, analyze market trends and needs, and interact with current and potential customers; (2) their evaluations regarding the efficacy of the social media usage by their firms in terms of impact on various dimensions of performance. According to the results of the fsQCA conducted, pathways that lead to an improvement of, respectively, brand awareness, brand reputation, and brand loyalty present some commonalities, but are also characterized by specificities, which suggest that different objectives in terms of brand management may require focusing attention on different aspects of social media management.

First of all, the analysis of necessary conditions highlights the importance of using social media in order to collect information. According to our results, in fact, the absence of this practice is a necessary condition for the absence of improvements regarding all the three dimensions analyzed: brand awareness, brand reputation, and brand loyalty. This suggests that, in order to obtain benefits concerning brand management performance, firms need to exploit the potentialities of this specific medium and, in particular, the opportunities for a two-way communication and the development of knowledge regarding current and potential customers.

Other two managerial practices appeared to be relevant for the three dimensions analyzed (brand awareness, brand reputation, and brand loyalty): the integration with other media and the internal dissemination of information obtained through social media.

Thus, it emerges the importance to have an integrated management of all the media used for communication (online and offline) or, at least, to share information gathered on social media with other organizational positions. This suggests the relevance of coordinating social media management with other firm activities, which can help the firm obtain consistency in its communication and initiatives, as well as increase its efficacy thanks to the synergistic use of different tools and communication channels.

According to the results of this study, a high level of social media integration with the management of other media is a sufficient condition for high levels of perceived improvement of both brand awareness and brand reputation.

However, it should be noted that in order to obtain good results in terms of brand loyalty, integration with other media is not sufficient, even if in some cases it can contribute to brand loyalty in combination with other choices. More precisely, integration needs to be associated with the usage of social media for information generation and, alternatively, high levels of internal information dissemination or the use of social media to complement (and not to substitute) other communication channels. This suggests that integrated management of social media can also help to improve brand loyalty, but this objective requires additional conditions, including a significant effort in terms of information gathering through social media. It is thus necessary to exploit also one of the peculiarities of social media that is associated with its interactive nature and the opportunities that it offers to generate information on customers and the market. Benefits in terms of brand loyalty can be accordingly obtained by integrating social media with other media, and exploiting their complementarity and their potentialities in terms of information collection and identification of market trends.

As concerns the internal sharing of information collected on the Internet, its relevance is highlighted by the results regarding both necessary and sufficient conditions. The absence of internal information dissemination is a necessary condition for the absence of improvements of brand awareness and brand reputation. At the same time, a high level of internal information dissemination is a sufficient condition for the improvement of brand reputation. This result may be interpreted as a consequence of the importance that internal sharing of information collected from social media has for obtaining the internal consistency of firm communication and fulfilling customers' needs, which may help the firm to improve brand reputation.

However, internal information dissemination is not a sufficient condition for brand awareness, which can be enhanced by combining internal information sharing with the complementary use of social media. To increase brand awareness, firms need not only to spread internally the information gathered on social media but also to use these media in addition to other tools (and not as a substitute for other channels). Social media have some specificities regarding the level of interactivity and targets that they can reach. Thus, they may be used in order to contact audiences that are not reached through other media or to improve communication with interlocutors that attributes importance to two-way communication and engagement. In this perspective, better results can be achieved by using them in addition to other media with complementary characteristics. On the other hand, using social media as a substitute for other media might limit the potential improvement of brand awareness, even in the presence of internal information sharing, because it might weaken the ability to reach targets less exposed to social media or the efficacy of communication. 
As a matter of fact, findings reveal that combining a high level of internal information dissemination with complementary use of social media is another possible way to obtain better results in terms of brand loyalty. Alternatively, brand loyalty can be achieved by combining high levels of internal information communication with both an intensive use of social media for information generation and the integrated management of all media. In order to improve brand loyalty, it is necessary to combine internal information sharing with an effort of coordinating the different communication channels and exploiting the peculiarities of social media (in terms of potentialities of information generation and/or complementarity with other media).

However, these combinations play only a secondary role in explaining how firms can obtain brand loyalty improvements. In this respect, the most interesting result deals with the role played by responsiveness. Social media responsiveness corresponds to the capability to monitor the market through social media and to provide prompt responses. Responsiveness is the only sufficient and core condition that allows brand loyalty to be boosted. A significant level of interactivity and reactivity to needs and trends observed through social media helps the firm in enhancing its relationship with customers and increasing their loyalty. This capability thus appears to be crucial. It is interesting to note that responsiveness does not appear among the conditions that lead to brand awareness and reputation improvements, suggesting that different objectives of brand management require the exploitation of different potentialities of social media.

\section{Implications, Limitations and Future Research}

This study aims to provide a contribution to the literature on branding and social media by analyzing managerial choices regarding social media use and management that are associated with better results in terms of brand awareness, brand reputation, and brand loyalty. According to the findings, the mode of using social media by firms appears to affect the perceived impact on brand performances, and different conditions (in terms of managerial choices) turn out to be related to improvements in, respectively, brand awareness, brand reputation and brand loyalty.

Overall, results highlight the need to exploit the potentialities of information generation of social media and the importance of integrating the management of social media with other media, and of sharing information gathered from social media within the organization. Coordinating activities and sharing information may help the firm create consistent brand communication across different media, and increase the efficacy of its communication. Social media represent one of the tools of the communication mix, whose effectiveness is enhanced by coordinating their use with that of other communication tools and by sharing information internally.

Moreover, results suggest the importance of exploiting the different potentialities that characterize social media, and especially the possibility to use information gathered from social media and the opportunity to provide a prompt response to current and potential customers (by communicating with them or by adopting initiatives and changes aimed at responding to their needs). In particular, responsiveness appears crucial to boosting brand loyalty through social media.

These findings have relevant implications from the managerial point of view, since they provide a better understanding of how firms may use social media in order to foster brand awareness, brand reputation and brand loyalty. They also highlight the fact that specific objectives in terms of brand management (improvement of brand awareness, brand reputation or brand loyalty) may require attention to be paid to different aspects of social media management. Finally, results suggest managers should avoid separating social media management from other firm activities, since the efficacy of social media in improving brand performance needs the firm's capability to share information gathered from social media internally, integrate social media with other communication tools, and define and implement responses to requests and needs that have emerged.

The present work also has some limitations that suggest directions for future research. Outcome conditions in the tested models correspond to the evaluations of interviewed managers regarding the benefits of the use of social media in terms of their firms' brand awareness, brand reputation and brand loyalty. The use of subjective measures was due to the difficulties in evaluating the contribution of social media usage and management to the main brands success measures (Schultz \& Block, 2012; Schultz \& Peltier, 2013), and due to the fact that managers are the subjects with the highest level of information about their firms (Hambrick \& Mason, 1984). In order to overcome this limitation, future research might try to combine managers' perceptions with direct measures of changes in brand performance, even if it would be very difficult to distinguish which the impact of social media is. In addition, the study conducted a first exploratory analysis of conditions that may lead to improvements of brand awareness, reputation and loyalty. Further research is needed to better understand cause-effect relationships and to investigate the potential relevance of other managerial choices regarding social media usage. Finally, this study focused only on firms operating in Italy, and it would be interesting to extend the 
analysis to other countries.

\section{References}

Aaker, D. A. (1991). Managing brand equity: Capitalizing on the value of a brand name. New York: The Free Press.

Aaker, D. A. (1992). The Value of Brand Equity. Journal of Business Strategy, 13(4), 27-32. http://doi.org/10.1108/eb039503

Agnihotri, R., Dingus, R., Hu, M. Y., \& Krush, M. T. (2016). Social media: Influencing customer satisfaction in B2B sales. Industrial Marketing Management, 53, 172-180. http://doi.org/10.1016/j.indmarman.2015.09.003

Alberghini, E., Cricelli, L., \& Grimaldi, M. (2014). A methodology to manage and monitor social media inside a company: a case study. Journal of Knowledge Management, 18(2), 255-277. http://doi.org/10.1108/JKM-10-2013-0392

Anseel, F., Lievens, F., Schollaert, E., \& Choragwicka, B. (2010). Response Rates in Organizational Science, 1995-2008: A Meta-analytic Review and Guidelines for Survey Researchers. Journal of Business and Psychology, 25(3), 335-349. http://doi.org/10.1007/s10869-010-9157-6

Berger, J., \& Milkman, K. L. (2012). What Makes Online Content Viral? Journal of Marketing Research, 49(2), 192-205. http://doi.org/10.1509/jmr.10.0353

Booth, N., \& Matic, J. A. (2011). Mapping and leveraging influencers in social media to shape corporate brand perceptions. Corporate Communications: An International Journal, 16(3), 184-191. http://doi.org/10.1108/13563281111156853

Brodie, R. J., Hollebeek, L. D., Juric, B., \& Ilić,, A. (2011). Customer Engagement: Conceptual Domain, Fundamental Propositions, and Implications for Research. Journal of Service Research, 14(3), 252-271. http://doi.org/10.1177/1094670511411703

Chappuis, B., Gaffey, B., \& Parvizi, P. (2011). Are your customers becoming digital junkies?

Cycyota, C. S., \& Harrison, D. A. (2006). What (Not) to Expect When Surveying Executives. Organizational Research Methods, 9(2), 133-160. http://doi.org/10.1177/1094428105280770

Dalla Pozza, I. (2014). Multichannel management gets "social." European Journal of Marketing, 48(7/8), 1274-1295.

De Chernatony, L. (1999). Brand Management Through Narrowing the Gap Between Brand Identity and Brand Reputation. Journal of Marketing Management, 15(1-3), 157-179. http://doi.org/10.1362/026725799784870432

De Vries, L., Gensler, S., \& Leeflang, P. S. H. (2017). Effects of Traditional Advertising and Social Messages on Brand-Building Metrics and Customer Acquisition. Journal of Marketing, 81(5), 1-15. http://doi.org/10.1509/jm.15.0178

Dijkmans, C., Kerkhof, P., \& Beukeboom, C. J. (2015). A stage to engage: Social media use and corporate reputation. Tourism Management, 47, 58-67. http://doi.org/10.1016/j.tourman.2014.09.005

Erdoğmuş, İ. E., \& Çiçek, M. (2012). The Impact of Social Media Marketing on Brand Loyalty. Procedia Social and Behavioral Sciences, 58, 1353-1360. http://doi.org/10.1016/j.sbspro.2012.09.1119

Fiss, P. C. (2007). A set-theoretic approach to organizational configurations. Academy of Management Review, 32(4), 1180-1198. http://doi.org/10.5465/AMR.2007.26586092

Fiss, P. C. (2011). Building better causal theories: A fuzzy set approach to typologies in organization research. Academy of Management Journal, 54(2), 393-420. http://doi.org/10.5465/AMJ.2011.60263120

Fombrun, C. J., \& Rindova, V. (1996). Who's tops and who decides? The social construction of corporate reputations. New York University, Stern School of Business, Working Paper.

Gallaugher, J., \& Ransbotham, S. (2010). Social media and customer dialog management at Starbucks. MIS Quarterly Executive, 9(4).

Godey, B., Manthiou, A., Pederzoli, D., Rokka, J., Aiello, G., Donvito, R., \& Singh, R. (2016). Social media marketing efforts of luxury brands: Influence on brand equity and consumer behavior. Journal of Business Research, 69(12), 5833-5841. http://doi.org/10.1016/j.jbusres.2016.04.181 
Habibi, M. R., Laroche, M., \& Richard, M. O. (2014). The roles of brand community and community engagement in building brand trust on social media. Computers in Human Behavior, 37, 152-161. http://doi.org/10.1016/j.chb.2014.04.016

Haenlein, M. (2017). How to date your clients in the 21st century: Challenges in managing customer relationships in today's world. Business Horizons, 60(5), 577-586. http://doi.org/10.1016/j.bushor.2017.06.002

Hambrick, D. C., \& Mason, P. A. (1984). Upper Echelons: The Organization as a Reflection of Its Top Managers. Academy of Management Review, 9(2), 193-206. http://doi.org/10.5465/AMR.1984.4277628

Heydari, A., \& Laroche, M. (2018). Cross-Cultural Study of Social Media-Based Brand Communities: An Abstract. In Krey N., Rossi P. (Eds.), Back to the Future: Using Marketing Basics to Provide Customer Value. AMSAC 2017. Developments in Marketing Science: Proceedings of the Academy of Marketing Science. Springer, Cham (pp. 331-332). http://doi.org/10.1007/978-3-319-66023-3_115

Hollebeek, L. D., Glynn, M. S., \& Brodie, R. J. (2014). Consumer Brand Engagement in Social Media: Conceptualization, Scale Development and Validation. Journal of Interactive Marketing, 28(2), 149-165. http://doi.org/10.1016/j.intmar.2013.12.002

Hsu, L., \& Lawrence, B. (2016). The role of social media and brand equity during a product recall crisis: A shareholder value perspective. International Journal of Research in Marketing, 33(1), 59-77. http://doi.org/10.1016/j.ijresmar.2015.04.004

Hutter, K., Hautz, J., Dennhardt, S., \& Füller, J. (2013). The impact of user interactions in social media on brand awareness and purchase intention: the case of MINI on Facebook. Journal of Product \& Brand Management, 22(5/6), 342-351. http://doi.org/10.1108/JPBM-05-2013-0299

Ismail, A. R. (2017). The influence of perceived social media marketing activities on brand loyalty. Asia Pacific Journal of Marketing and Logistics, 29(1), 129-144. http://doi.org/10.1108/APJML-10-2015-0154

Jin, S. A. (2012). The potential of social media for luxury brand management. Marketing Intelligence \& Planning, 30(7), 687-699. http://doi.org/10.1108/02634501211273805

Kaplan, A. M., \& Haenlein, M. (2010). Users of the world, unite! The challenges and opportunities of Social Media. Business Horizons, 53(1), 59-68.

Keller, K. L. (1993). Conceptualizing, Measuring, and Managing Customer-Based Brand Equity. Journal of Marketing, 57(1), 1-22. http://doi.org/10.2307/1252054

Keller, K. L. (2008). Strategic brand management: building, measuring, and managing brand equity. Prentice Hall, Upper Saddle River, NJ.

Kemp, S. (2017). 2017 Digital Yearbook. Internet, social media, and mobile data for 239 countries around the world.

Killian, G., \& McManus, K. (2015). A marketing communications approach for the digital era: Managerial guidelines for social media integration. Business Horizons, 58(5), 539-549.

Kim, A. J., \& Ko, E. (2010). Impacts of Luxury Fashion Brand's Social Media Marketing on Customer Relationship and Purchase Intention. Journal of Global Fashion Marketing, 1(3), 164-171. http://doi.org/10.1080/20932685.2010.10593068

Kim, A. J., \& Ko, E. (2012). Do social media marketing activities enhance customer equity? An empirical study of luxury fashion brand. Journal of Business Research, 65(10), 1480-1486. http://doi.org/10.1016/j.jbusres.2011.10.014

Kotler, P., \& Keller, K. L. (2007). Il marketing del nuovo millennio. Pearson Italia Spa.

Kozinets, R. V, de Valck, K., Wojnicki, A. C., \& Wilner, S. J. (2010). Networked Narratives: Understanding Word-of-Mouth Marketing in Online Communities. Journal of Marketing, 74(2), 71-89. http://doi.org/10.1509/jmkg.74.2.71

Kumar, V., Choi, J. B., \& Greene, M. (2017). Synergistic effects of social media and traditional marketing on brand sales: capturing the time-varying effects. Journal of the Academy of Marketing Science, 45(2), 268-288. http://doi.org/10.1007/s11747-016-0484-7

Laroche, M., Habibi, M. R., \& Richard, M. O. (2013). To be or not to be in social media: How brand loyalty is affected by social media? International Journal of Information Management, 33(1), 76-82. 
http://doi.org/10.1016/j.ijinfomgt.2012.07.003

Leischnig, A., \& Kasper-Brauer, K. (2015). Employee Adaptive Behavior in Service Enactments. Journal of Business Research, 68(2), 273-280. http://doi.org/10.1016/j.jbusres.2014.07.008

Mangold, W. G., \& Faulds, D. J. (2009). Social media: The new hybrid element of the promotion mix. Business Horizons, 52(4), 357-365. http://doi.org/10.1016/j.bushor.2009.03.002

Neff, J. (2014). World's biggest advertiser P\&G shifts focus to sampling.

Oliver, R. (1999). Whence Consumer Loyalty? The Journal of Marketing, 63, 33-44.

Qualman, E. (2013). Social media video 2013.

Raab, C., Berezan, O., Krishen, A. S., \& Tanford, S. (2016). What's in a Word? Building Program Loyalty through Social Media Communication. Cornell Hospitality Quarterly, 57(2), 138-149. http://doi.org/10.1177/1938965515619488

Ragin, C. C. (2000). Fuzzy-set Social Science. Chicago: University of Chicago Press.

Ragin, C. C. (2006). Set relations in social research: Evaluating their consistency and coverage. Political Analysis, 14(3), 291-310. http://doi.org/10.1093/pan/mpj019

Ragin, C. C. (2008). Redesigning Social Inquiry: Fuzzy Sets and Beyond. University of Chicago Press.

Ragin, C. C., \& Fiss, P. C. (2008). Net Effects versus Configurations: An Empirical Demonstration. In Redesigning Social Inquiry: Fuzzy Sets and Beyond. University of Chicago Press.

Ragin, C. C., \& Sean, D. (2016). Fuzzy-Set/Qualitative Comparative Analysis 3.0. Irvine, California: Department of Sociology, University of California.

Rapp, A., Beitelspacher, L. S., Grewal, D., \& Hughes, D. E. (2013). Understanding social media effects across seller, retailer, and consumer interactions. Journal of the Academy of Marketing Science, 41(5), 547-566. http://doi.org/10.1007/s11747-013-0326-9

Schneider, C. Q., \& Wagemann, C. (2012). Set-Theoretic Methods for the Social Sciences. A Guide to Qualitative Comparative Analysis (Cambridge). New York.

Schneider, M. R., \& Eggert, A. (2014). Embracing complex causality with the QCA method: An invitation. Journal of Business Market Management, 7(1), 312-328.

Schneider, M. R., Schulze-Bentrop, C., \& Paunescu, M. (2010). Mapping the institutional capital of high-tech firms: A fuzzy-set analysis of capitalist variety and export performance. Journal of International Business Studies, 41(2), 246-266. http://doi.org/10.1057/jibs.2009.36

Schultz, D. E., \& Block, M. P. (2012). Rethinking Brand Loyalty in an Age of Interactivity. IUP Journal of Brand Management, 9(3), 21-39.

Schultz, D. E., \& Peltier, J. (Jimmy). (2013). Social media's slippery slope: challenges, opportunities and future research directions. Journal of Research in Interactive Marketing, 7(2), 86-99. http://doi.org/10.1108/JRIM-12-2012-0054

Swani, K., Milne, G. R., Brown, B. P., Assaf, A. G., \& Donthu, N. (2017). What messages to post? Evaluating the popularity of social media communications in business versus consumer markets. Industrial Marketing Management, 62, 77-87. http://doi.org/10.1016/j.indmarman.2016.07.006

Tiago, M. T. P. M. B., \& Veríssimo, J. M. C. (2014). Digital marketing and social media: Why bother? Business Horizons, 57(6), 703-708. http://doi.org/10.1016/j.bushor.2014.07.002

Trainor, K. J., Andzulis, J., Rapp, A., \& Agnihotri, R. (2014). Social media technology usage and customer relationship performance: A capabilities-based examination of social CRM. Journal of Business Research, 67(6), 1201-1208. http://doi.org/10.1016/j.jbusres.2013.05.002

Tsimonis, G., \& Dimitriadis, S. (2014). Brand strategies in social media. Marketing Intelligence \& Planning, 32(3), 328-344. http://doi.org/10.1108/MIP-04-2013-0056

Vernuccio, M., \& Ceccotti, F. (2015). Strategic and organisational challenges in the integrated marketing communication paradigm shift: A holistic vision. European Management Journal, 33(6), 438-449.

Woodside, A. G. (2013). Moving beyond multiple regression analysis to algorithms: Calling for adoption of a paradigm shift from symmetric to asymmetric thinking in data analysis and crafting theory. Journal of Business Research, 66(4), 463-472. https://doi.org/10.1016/j.jbusres.2012.12.021 
Yoshida, M., Gordon, B. S., Nakazawa, M., Shibuya, S., \& Fujiwara, N. (2018). Bridging the gap between social media and behavioral brand loyalty. Electronic Commerce Research and Applications, 28, 208-218. http://doi.org/10.1016/j.elerap.2018.02.005

Yuksel, M., Milne, G. R., \& Miller, E. G. (2016). Social media as complementary consumption: the relationship between consumer empowerment and social interactions in experiential and informative contexts. Journal of Consumer Marketing, 33(2), 111-123. http://doi.org/10.1108/JCM-04-2015-1396

\section{Copyrights}

Copyright for this article is retained by the author(s), with first publication rights granted to the journal.

This is an open-access article distributed under the terms and conditions of the Creative Commons Attribution license (http://creativecommons.org/licenses/by/4.0/). 